\title{
Volatile Components in the Flower, Pedicellate Ovary and Aqueous Residue of Cymbidium sp. (ORCHIDACEAE)
}

\author{
Víctor García Gaytán ${ }^{1}$, María de las Nieves Rodríguez Mendoza ${ }^{1}$, Marcos Soto Hernández², \\ Libia I. Trejo-Téllez ${ }^{1}$, Martha E. Pedraza Santos ${ }^{3}$, Guadalupe Valdovinos Ponce ${ }^{4}$ \\ ${ }^{1}$ Postgrado en Edafología, Colegio de Postgraduados, Texcoco, México; ${ }^{2}$ Postgrado en Botánica, Colegio de Postgraduados, Texcoco, \\ México; ${ }^{3}$ Facultad de Agrobiología "Presidente Juárez", Uruapan, México; ${ }^{4}$ Postgrado en Fitosanidad, Colegio de Postgraduados, \\ Texcoco, México. \\ Email: msoto@colpos.mx
}

Received September $2^{\text {nd }}, 2013$; revised October $6^{\text {th }}, 2013$; accepted October $15^{\text {th }}, 2013$

Copyright (C) 2013 Víctor García Gaytán et al. This is an open access article distributed under the Creative Commons Attribution License, which permits unrestricted use, distribution, and reproduction in any medium, provided the original work is properly cited.

\begin{abstract}
Cymbidium sp. has several ornamental, medicinal and cosmetic uses. Essential oils were obtained through extraction by hydrodistillation of flower and pedicellate ovary. The chromatographic profile was obtained by thin layer chromatography (TLC), combined with gas chromatography-mass spectrometry (GC/MS), for the identification and relative quantification of various substances in three samples from the orchid (flower, pedicellate ovary and aqueous residue). With TLC, five compounds were identified in the flower, with the most abundant being terpineol, linalool and zingiberene, and five in the pedicellate ovary, with borneol, cineole, and $\beta$-bisabolene being in the greatest concentration, while for the aqueous residue, the most abundant was geraniol. Using GC/MS, 25 volatile components associated with the flower were identified, of which the most abundant were linalool (22.92\%), 4-methyl-phenol (15.07\%) and $p$-Menth-1-en-8-ol (12.32\%). In pedicellate ovaries, 13 components were identified, with the most abundant being 4-methyl-phenol (31.24\%), bicycle [4.4.0] dec-1-ene, 2-isopropyl-5-methyl-9-methylene-(17.74\%) and 2-hexanone (10.24\%), while in the aqueous residue 18 components were found, with the most abundant being 4-methyl-phenol (18.71\%) and 2- cyclohexen-1-ol (14.60\%).
\end{abstract}

Keywords: Thin Layer Chromatography; Gas Chromatography; Orchidaceae; Hydrodistillation

\section{Introduction}

Plants synthesize and emit chemical compounds that are not only beneficial to humans, but also play a key role in the survival and reproduction of these organisms, such as defense against herbivores and pathogens and mating attraction for pollination [1-3]. In orchids, the phytochemical compounds in roots, tubers, rhizomes, pseudobulbs and leaves have been used to treat a range of diseases [4-7]. The family Orchidaceae is the largest within the angiosperms, consisting of more than 35,000 species and about 750 genera. The family Orchidaceae, whose structural and anatomical characteristics are very diverse, is widely found in temperate and tropical regions, but not in Antarctica [8,9]. The genus Cymbidium provides an important commercial ornamental species; it is one of the most popular and sought-after orchids internationally due to its beautiful flowers. It has also been used in traditional medicine for the treatment of paralysis, boils and fever. Compounds with antibacterial and cytotoxic activity, such as phenanthrenes, have been isolated from the fresh roots of Cymbidium Great Flower Marie Laurencin. In Cymbidium goeringii, compounds have been isolated with hypotensive activity and diuretic activity (peptidoglycan monomer) [10,11]. The study and evaluation of the volatile compounds emitted by orchids and their possible medical applications is a broad and emerging research field $[12,13]$. Against this background, in this study, the volatile components in the flower, ovary and aqueous residue of Cymbidium sp. were isolated, identified and quantified in order to contribute to the chemical knowledge of this genus of orchid. 


\section{Materials and Methods}

The work was carried out in the Phytochemistry Laboratory at the Montecillo campus of the Colegio de Postgraduados. Fresh flowers of Cymbidium sp. were removed from the flower spike, and ovaries were separated from the flowers and cut into small pieces. The total amount of fresh flowers and ovary obtained was $549 \mathrm{~g}$ and $71.22 \mathrm{~g}$, respectively. Both were weighed using an OHAUS electronic digital scale (Model CT1200-S).

\subsection{Analysis of the Flower, Pedicellate Ovary and Aqueous Residue by Thin Layer Chromatography (TLC)}

Hydrodistillation was performed for three hours to extract the compounds in the flowers and pedicellate ovaries; $30 \mathrm{ml}$ of each distillate were collected, which made three extractions with $30 \mathrm{ml}$ of dichloromethane $\left(\mathrm{Cl}_{2} \mathrm{CH}_{2}\right)$ each. The organic extract was dried with anhydrous sodium sulfate, the solvent was evaporated using a rotary evaporator and the oil yield was obtained by weight differences. The compounds were stored in vials until analysis. The chromatographic profile was obtained by thin layer chromatography (TLC), using a silica gel $60 \mathrm{~F}_{254}$ plate with aluminum base $(10 \times 10 \mathrm{~cm})$. From the samples dissolved in dichloromethane, $10-20 \mu \mathrm{L}$ were taken and placed in a timely manner on the plate. This was developed in a system of toluene ethyl acetate $(93: 7 \mathrm{v}: \mathrm{v})$ with prior chromatographic chamber saturation. Developing was done with the reagent: $2 \%$ vanillin in $\mathrm{EtOH}$, $10 \%$ sulfuric acid in $\mathrm{EtOH}$, at $110^{\circ} \mathrm{C}$ for $5 \mathrm{~min}$ [14].

\subsection{Analysis of the Flower, Pedicellate Ovary and Aqueous Residue by Gas Chromatography-Mass Spectrometry (GC/MS)}

Quantitative analysis was performed by gas chromatography-mass spectrometry (GC/MS) with a gas chromatograph (HP-6890) coupled with a mass detector (HP5973). The separation was performed using an HP-5 ms capillary column $(5 \%$ phenyl methyl siloxane, $30 \mathrm{~m} \times$ $250 \mu \mathrm{m} \times 0.25 \mu \mathrm{m})$. The operating conditions of the chromatograph were: initial temperature of $60^{\circ} \mathrm{C}$ for 2 min, thereafter increasing $4^{\circ} \mathrm{C} \mathrm{min}{ }^{-1}$; final temperature was $250^{\circ} \mathrm{C}$, injection port at $250^{\circ} \mathrm{C}$; the split $10: 1$; helium gas flow at $1.5 \mathrm{~mL} \cdot \mathrm{min}^{-1}$, quadrupole at $230^{\circ} \mathrm{C}$ and 1388 mv voltage. An aliquot of the oil was diluted in $1 \mathrm{ml}$ of dichloromethane, with $1 \mu \mathrm{L}$ of the resulting solution being injected. Identification and quantification was based on retention times and rates, as well as data from the National Institute of Standards and Technology (NIST) mass spectra library.

\section{Results and Discussion}

\subsection{Characterization of the Components in the Flower, Pedicellate Ovary and Aqueous Residue by TLC}

Using the TLC technique, five components were identified in the essential oil of the flower of Cymbidium sp. five in the ovary oil and two in the aqueous residue (Figure 1). The components that stand out in the flower are terpineol with a retention factor (Rf) value of 0.14 and brown coloring, linalool with an Rf of 0.38 and blue coloring, zingiberene with an $\mathrm{Rf}$ of 0.52 and blue coloring and the presence of sesquiterpenoids with an $\mathrm{Rf}$ of 0.6 and violet coloring. In the ovary the components that stand out are: borneol with an Rf of 0.18 and brown coloring, cineole with an $\mathrm{Rf}$ of 0.4 and blue coloring, $\beta$ bisabolene with an $\mathrm{Rf}$ of 0.53 and blue coloring and the presence of other terpenes with an Rf of 0.58 and violet coloring. The TLC data contrast with the results of [15] who, in analyzing the floral components of two species of Cymbidium (C. faberi and C. virescens) by GC/MS, obtained $0.14 \% \alpha$-terpineol, $0.21 \%$ linalool, $0.65 \%$ zingeberene, $0.30 \% 1,8$-cineole and $0.31 \% \beta$-bisabolene.

\subsection{Identification and Quantification of the Substances in the Flower, Pedicellate Ovary and Aqueous Residue by GC/MS}

The GC/MS technique enabled detecting 21 components in the floral structure of Cymbidium sp. of which 19 were identified by comparing mass spectra and retention times (Figure 2). Table 1 lists the components identified from the chromatogram of the extracts, of which the most abundant are: linalool $(22.92 \%)$ with a retention time (Rt) of 10.30, 4-methylphenol (15.07\%) with an Rt of 16.07, p-Menth-1-en-8-ol (12.32\%) with an Rt of 12.19 and camphor (5.48\%) with an Rt of 10.14 .

In flowers of the orchid Dendrophylax lindenii (Lind-

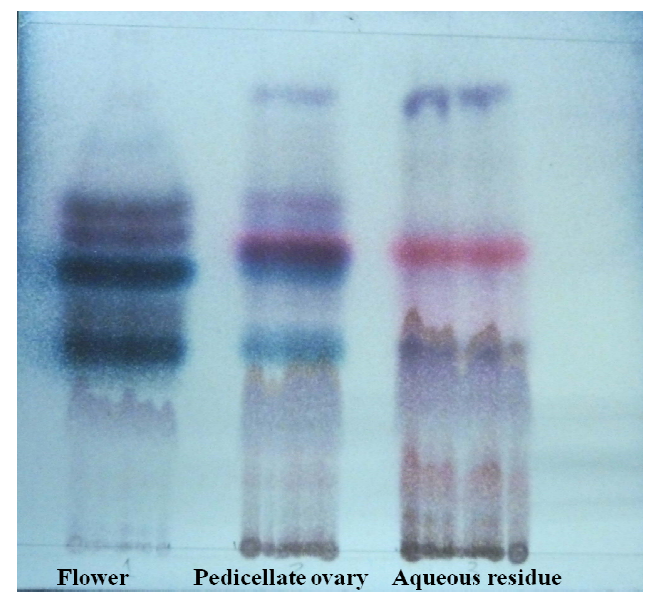

Figure 1. Analysis of the flower, ovary and aqueous residueof Cymbidium sp. by thin layer chromatography (TLC). 
Table 1. Components in the floral structure by GC/MS in Cymbidium sp.

\begin{tabular}{|c|c|c|c|}
\hline $\begin{array}{c}\text { Peak } \\
\text { number }\end{array}$ & $\begin{array}{c}\text { Retention } \\
\text { time }\end{array}$ & Compound name & $\%$ area \\
\hline 1 & 4.34 & 2-Hexanone & 1.55 \\
\hline 2 & 7.77 & 1-Hexanol & 2.11 \\
\hline 3 & 9.07 & Linalool oxide & 2.19 \\
\hline 4 & 9.43 & cis-Linalool oxide & 1.73 \\
\hline 5 & 10.14 & canphor & 5.48 \\
\hline 6 & 10.30 & Linalool & 22.92 \\
\hline 7 & 10.44 & 1-Octanol & 0.69 \\
\hline 8 & 10.75 & $\begin{array}{l}\text { Bicycle [2.2.1] heptan-3-one, } \\
\text { 6,6-dimethyl-2-methylene }\end{array}$ & 0.44 \\
\hline 9 & 10.9 & $(1 \mathrm{R})-(+)$-Norinone & 0.79 \\
\hline 10 & 11.1 & L-4-terpineol & 3.78 \\
\hline 11 & 11.47 & Myrtenal & 0.83 \\
\hline 12 & 11.72 & L-Pinocarveol & 4.77 \\
\hline 13 & 11.89 & unidentified & 7.35 \\
\hline 14 & 11.98 & Cryptone & 1.33 \\
\hline 15 & 12.19 & p-ment-1-en-8-ol & 12.32 \\
\hline 16 & 12.26 & L-Borneol & 4.64 \\
\hline 17 & 12.41 & cis-Verbenone & 0.48 \\
\hline 18 & 12.46 & unidentified & 1.59 \\
\hline 19 & 12.68 & D-Carvone & 0.79 \\
\hline 20 & 13.25 & Myrtenol & 3.67 \\
\hline 21 & 13.48 & 2,4-Decadienal, (E,E)- & 1.72 \\
\hline 22 & 13.66 & cis-Carveol & 1.20 \\
\hline 23 & 13.75 & 2,6-Octadien-1-ol, 3, 7-dimethyl- & 2.64 \\
\hline 24 & 16.07 & Phenol, 4-methyl- & 15.07 \\
\hline 25 & 17.58 & alpha-Bisabolool & 2.07 \\
\hline
\end{tabular}

ley) Bentham through analysis by GC/MS, a low percentage of linalool (5\%) was found [16]. By using GC/ MS to analyze the volatile components in the flowers of two species of Cymbidium (C. faberi and C. virescens) in Japan, linalool was identified in only $C$. faberi and at a very low concentration $(0.21 \%)$ [15]. Linalool is a highly sought-after aromatic compound in the fragrance industry. This monoterpene alcohol chemical has several biological activities, among which are antimicrobial, anti-inflammatory, antineoplastic and anti-oxidant properties. Additionally, several studies have confirmed the positive effects of this compound in the central nervous system; it also plays an important role in nature during the pollina- tion of plant species to thereby ensure their reproduction and survival [17]. In the case of the ovary extract and the aqueous residue, the most abundant components were 4-methylphenol (31.24 and $18.71 \%$, respectively) (Tables 2 and 3) with Rt values of 16.07 and 16.08 (Figures 3 and 4).

Phenolic compounds have been used as natural antioxidants and have become increasingly important for humans because of their medicinal benefits; moreover, their use as an additive in food preservation is also of great interest due to their reported antimicrobial activity [18-20].

Other compounds identified were bisabolol at a concentration of $2.07 \%$ and benzaldehyde at $1.49 \%$ in floral organ and aqueous residue, respectively. The percentages of these compounds are higher than those reported in flowers of $C$. faberi and $C$. virescens by [15], with percentages of $0.6 \%$ and $0.2 \%$ respectively for bisabolol and benzaldehyde. A phytochemical study of Cymbidium aloifolium with a extract of $75 \%$ methanol found a high content of compounds such as flavonoids, reducing sugars,

Table 2. Components in the pedicellate ovary by GC/MS in Cymbidium sp.

\begin{tabular}{|c|c|c|c|}
\hline $\begin{array}{c}\text { Peak } \\
\text { number }\end{array}$ & $\begin{array}{l}\text { Retention } \\
\text { time }\end{array}$ & Compound name & $\%$ area \\
\hline 1 & 4.33 & 2-Hexanone & 10.24 \\
\hline 2 & 4.68 & 3-Pentanol, 3-methyl- & 1.41 \\
\hline 3 & 5.69 & 3-Hexanol & 1.48 \\
\hline 4 & 6.01 & Hexane,1-methoxy- & 2.78 \\
\hline 5 & 6.14 & Cyclopentanol, 1-methyl- & 3.04 \\
\hline 6 & 7.62 & Cyclopentanol, 3-methyl- & 1.20 \\
\hline 7 & 9.32 & 2-Cyclohexen-1-ol & 1.72 \\
\hline 8 & 10.28 & Linalool & 5.46 \\
\hline 9 & 12.17 & p-menth-1-en-8-ol & 4.62 \\
\hline 10 & 13.26 & cis-Geraniol & 1.38 \\
\hline 11 & 13.48 & unidentified & 2.43 \\
\hline 12 & 13.75 & trans-Geraniol & 4.18 \\
\hline 13 & 14.69 & unidentified & 1.64 \\
\hline 14 & 15.01 & 1-Nonadecene & 1.69 \\
\hline 15 & 15.55 & Cembrane & 1.32 \\
\hline 16 & 15.75 & unidentified & 1.72 \\
\hline 17 & 16.07 & Phenol, 4-methyl- & 31.24 \\
\hline 18 & 16.18 & unidentified & 4.50 \\
\hline 19 & 17.21 & $\begin{array}{c}\text { Bicycle [4.4.0] dec-1-ene, } \\
\text { 2-isopropyl-5-methyl-9-methylene- }\end{array}$ & 17.74 \\
\hline
\end{tabular}




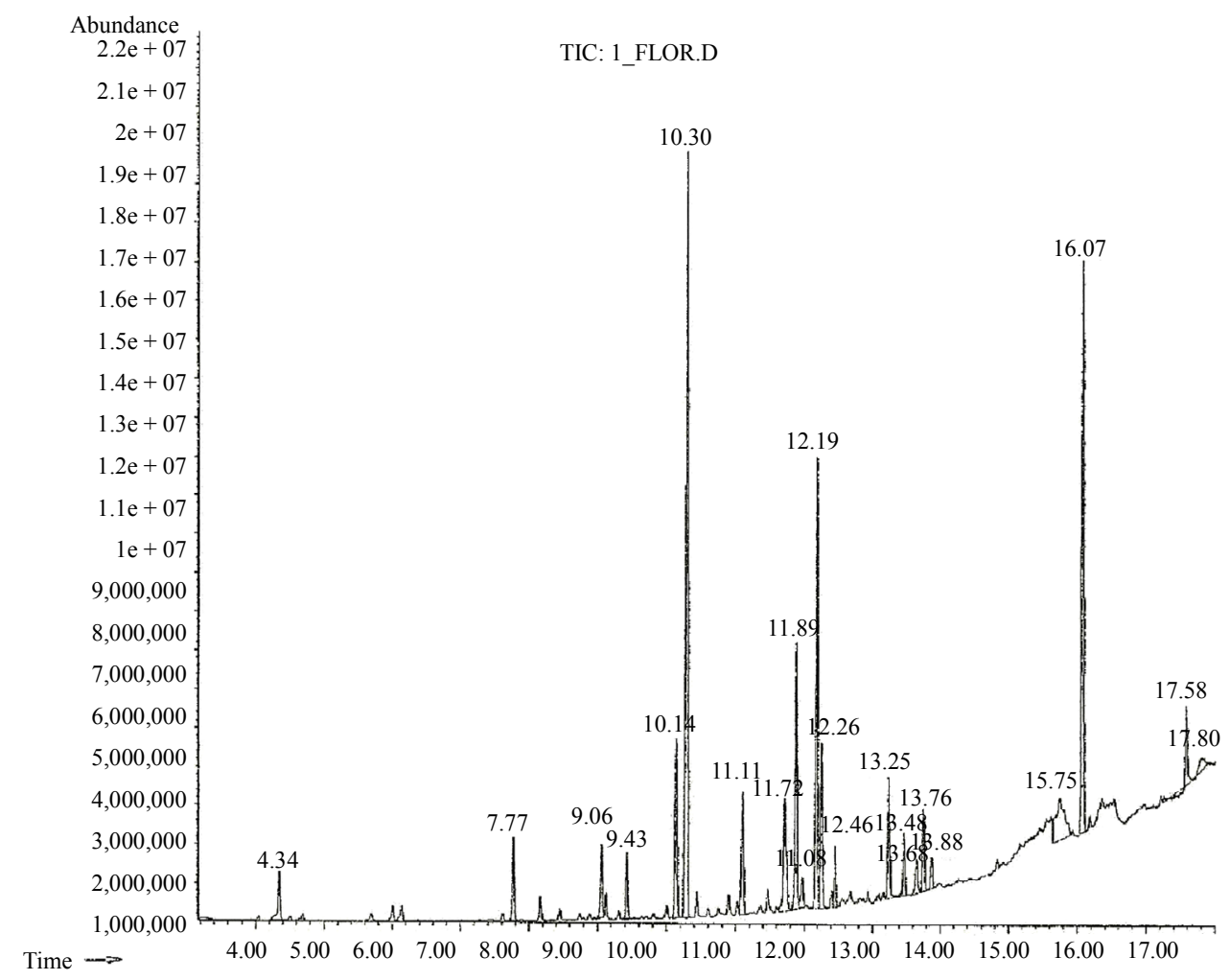

Figure 2. Identification and quantification of the substances in the flower by GC/MS in Cymbidium sp.

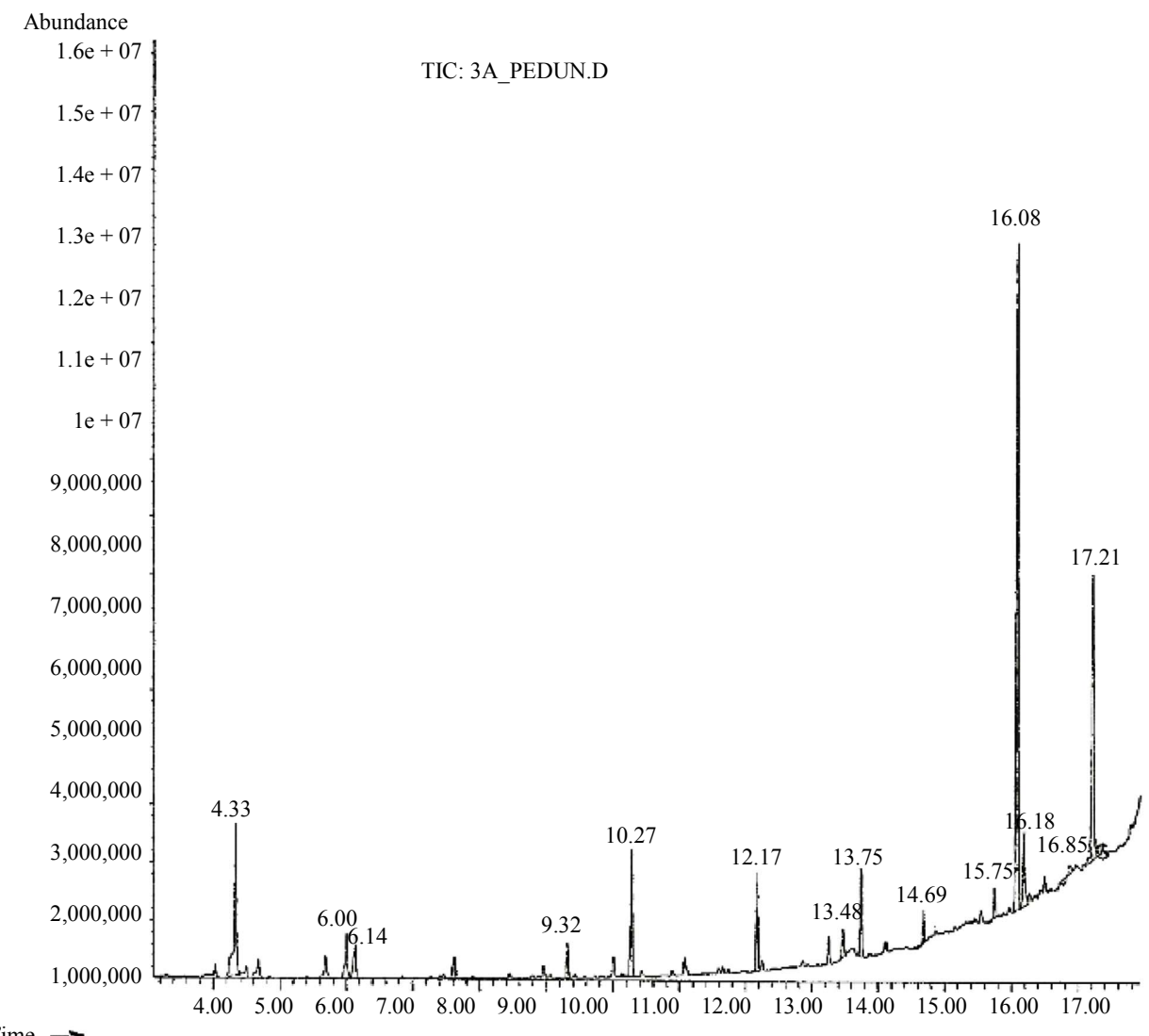

Figure 3. Identification and quantification of the substances in the ovary by GC/MS in Cymbidium sp. 


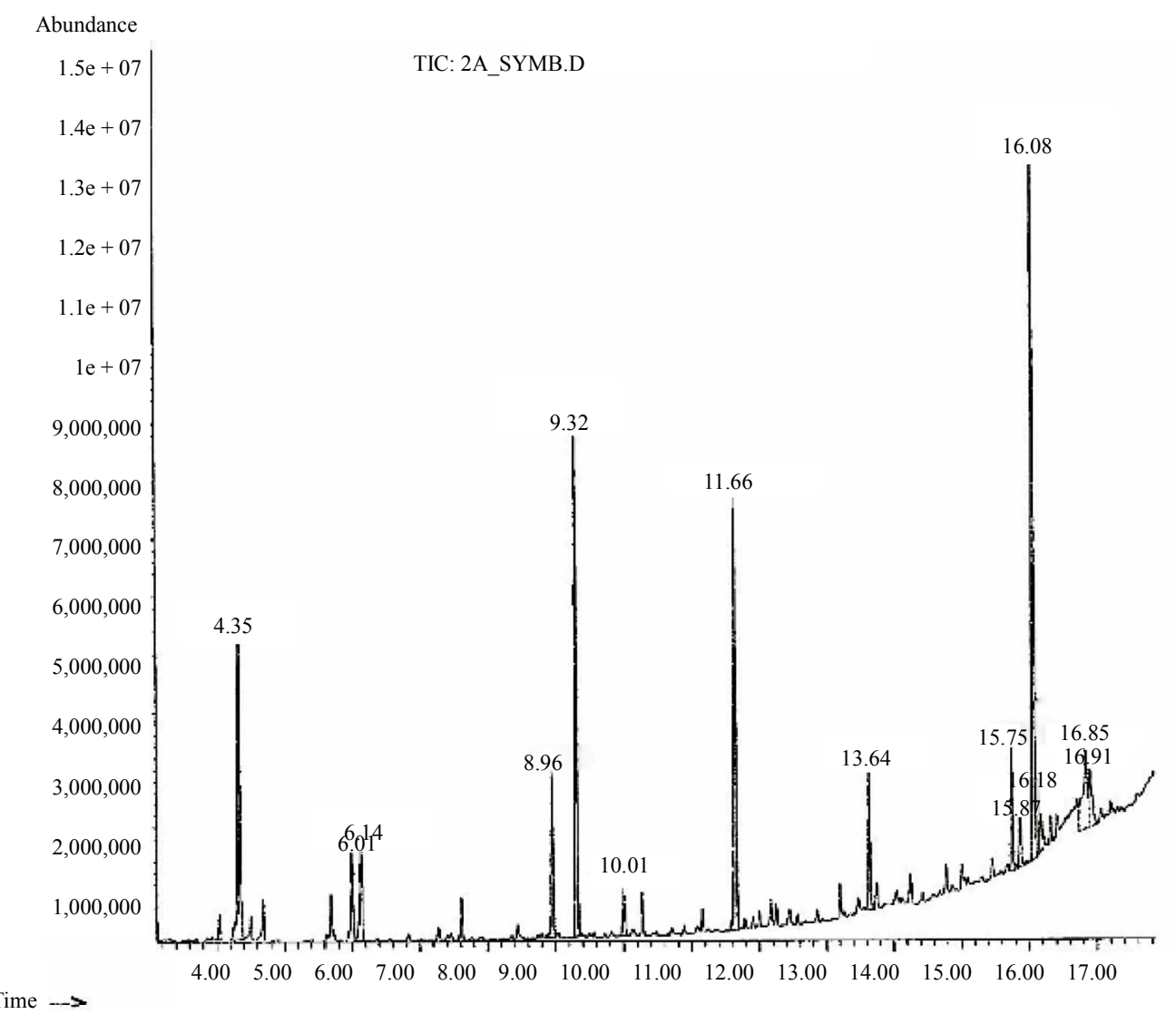

Figure 4. Identification and quantification of the substances in aqueous residue by GC/MS in Cymbidium sp.

Table 3. Components in the aqueous residue by GC/MS in Cymbidium sp.

\begin{tabular}{|c|c|c|c|}
\hline $\begin{array}{c}\text { Peak } \\
\text { number }\end{array}$ & $\begin{array}{c}\text { Retención } \\
\text { time }\end{array}$ & Compound name & $\%$ Area \\
\hline 1 & 4.35 & 2-Hexanone & 9.40 \\
\hline 2 & 2.69 & 3-Methyl-3-pentanol & 1.50 \\
\hline 3 & 5.69 & 3-Hexanol & 1.45 \\
\hline 4 & 6.01 & 2-Pentanol, 4-methyl- & 2.72 \\
\hline 5 & 6.14 & Cyclopentanol, 1-methyl- & 3.25 \\
\hline 6 & 6.61 & Cyclopentanol, 3-methyl- & 1.27 \\
\hline 7 & 8.86 & 2-Cyclohexen-1-one & 5.12 \\
\hline 8 & 9.33 & 2-Cyclohexen-1-ol & 14.60 \\
\hline 9 & 10.01 & Benzaldehyde & 1.49 \\
\hline 10 & 10.28 & Linalool & 1.25 \\
\hline 11 & 11.66 & 2-Chlorocyclohexanol & 12.65 \\
\hline 12 & 12.17 & L- $\alpha$-Terpineol & 0.95 \\
\hline 13 & 13.64 & Hexanoic acid & 4.19 \\
\hline 14 & 13.75 & 2,6-Octadien-1-ol, 3,7-dimethyl- & 0.70 \\
\hline 15 & 16.08 & Phenol, 4-methyl- & 18.71 \\
\hline
\end{tabular}

Continued

\begin{tabular}{cccc}
\hline 16 & 16.18 & unidentified & 2.80 \\
17 & 16.42 & 1-Hexacosene & 1.83 \\
18 & 16.71 & $\begin{array}{c}\text { E,E,Z-1,3,12- } \\
\text { Nonadecatriene-5,14-diol }\end{array}$ & 6.81 \\
19 & 16.85 & (R)-(-)-14-Methyl-8-hexadecin-1-ol & 6.81 \\
20 & 16.91 & Octacosanol & 3.39 \\
\hline
\end{tabular}

cyanogenic glycosides, terpenes and tannins; however, each of the components were not characterized [21]. Phytochemical studies on leaves of 142 species in 72 genera of the family Orchidaceae, including Cymbidium, [22] showed that concentrations of volatile components in a species varies considerably from one geographic region to another; the most common compounds were flavone C-glycosides (53\%) and flavonoids (37\%); however, the compounds were not uniform and their distribution showed a strong correlation with the geographical location of the plant.

\section{Conclusion}

In the floral organs of the orchid Cymbidium sp., we identified a larger number of terpenes such as linalool 
(22.29\%), as well as 4-methyl-phenol and $p$-Menth-1-en8 -ol, than in the ovary and aqueous residue where the component with the greatest concentration in both cases was 4-methyl-phenol (31.24\% and $18.71 \%$, respectively), which provides evidence of their biological properties and potential in cosmetics and perfumery. The TLC and GC/MS methods of analysis enabled identifying the compounds in the floral organs, ovary and aqueous residue of Cymbidium sp. that had not been carried out in previous studies.

\section{Acknowledgments}

Victor García Gaytan wishes to thank the LPI-4 Priority Line of Research (Agribusiness, Agro-ecotourism and Landscape Architecture), Mexico's National Science and Technology Council (CONACYT) and the Phytochemistry Laboratory at the Montecillo Campus of the Colegio de Postgraduados for their support and sponsorship of this research. Also thanks to M.Sc Manolo Muñiz for his technical assistance in the operation of the GC/EM analysis.

\section{REFERENCES}

[1] A. Jurgens and A. M. Viljoen, "Chemical Diversity and Biological Functions of Plant Volatiles," South African Journal of Botany, Vol. 76, No. 4, 2010, pp. 607-611. http://dx.doi.org/10.1016/j.sajb.2010.09.008

[2] F. P. Schiestl, "The Evolution of Floral Scent and Insect Chemical Communication," Ecology Letters, Vol. 13, No. 5, 2010, pp. 643-56. http://dx.doi.org/10.1111/j.1461-0248.2010.01451.x

[3] C. Soler, M. Hossaert-McKey, B. Buatois, J. M. Bessiére, B. Schatz and M. Proffit, "Geographic Variation of Floral Scent in a Highly Specialized Pollination Mutualism," Phytochemistry, Vol. 72, No. 1, 2011, pp. 74-81. http://dx.doi.org/10.1016/i.phytochem.2010.10.012

[4] M. Cai, Y. Zhou, S. Gesang, C. Bianba and L. S. Ding, "Chemical Fingerprint Analysis of Rhizomes of Gymnadenia conopsea by HPLC-DAD-MSn," Journal of Chromatography B, Vol. 844, No. 2, 2006, pp. 301-307. http://dx.doi.org/10.1016/j.jchromb.2006.07.043

[5] C. F. Allen, M. E'dwards, L. M. Williamson, W. Kitson-Piggott, H. U. Wagner, B. Camara and C. J. Hospedales, "Sexually Transmitted Infection Service Use and Risk Factors for HIV Infection among Female Sex Workers in Georgetown, Guyana," Journal of Acquired Immune Deficiency Syndromes, Vol. 43, No. 1, 2006, pp. 96-101.

http://dx.doi.org/10.1097/01.qai.0000226794.23840.80

[6] M. Adams, W. Alther, M. Kessler, M. Kluge and M. Hamburger, "Malaria in the Renaissance: Remedies from European Herbals from the 16th and 17th Century," Journal of Ethnopharmacology, Vol. 133, No. 2, 2011, pp. 278-88.

http://dx.doi.org/10.1016/j.jep.2010.10.060
[7] M. M. Hossain, "Therapeutic Orchids: Traditional Uses and Recent Advances-An Overview," Fitoterapia, Vol. 82, No. 2, 2011, pp. 102-40. http://dx.doi.org/10.1016/j.fitote.2010.09.007

[8] N. W. Albert, S. Arathoon, V. E. Collette, K. E. Schwinn, P. E. Jameson, D. H. Lewis, H. Zhang and K. M. Davies, "Activation of Anthocyanin Synthesis in Cymbidium Orchids: Variability between Known Regulators," Plant Cell Tissue and Organ Culture, Vol. 100, No. 3, 2010, pp. 355-360. http://dx.doi.org/10.1007/s11240-009-9649-0

[9] K. Yoshikawa, T. Ito, K. Iseki, C. Baba, H. Imagawa, Y. Yagi, H. Morita, Y. Asakawa, S. Kawano and T. Hashimoto, "Phenanthrene Derivatives from Cymbidium Great Flower Marie Laurencin and Their Biological Activities," Journal of Natural Products, Vol. 75, No. 4, 2012, pp. 605-609. http://dx.doi.org/10.1021/np200788u

[10] M. M. Hossain, M. Sharma and P. Pathak, "Cost Effective Protocol for in Vitro Mass Propagation of Cymbidium aloifolium (L.) Sw.-A Medicinally Important Orchid," Engineering in Life Sciences, Vol. 9, No. 6, 2009, pp. 444-453. http://dx.doi.org/10.1002/elsc.200900015

[11] K. Watanabe, R. Tanaka, H. Sakurai, K. Iguchi, Y. Yamada, C. S. Hsu, C. Sakuma, H. Kikuchi, H. Shibayama and T. Kawai, "Structure of Cymbidine A, a Monomeric Peptidoglycan-Related Compound with Hypotensive and Diuretic Activities, Isolated from a Higher Plant, Cymbidium goeringii (Orchidaceae)," Chemical and Pharmaceutical Bulletin, Vol. 55, No. 5, 2007, pp. 780-783. http://dx.doi.org/10.1248/cpb.55.780

[12] J. Gershenzon and N. Dudareva, "The Function of Terpene Natural Products in the Natural World," Nature Chemical Biology, Vol. 3, No. 7, 2007, pp. 408-414. http://dx.doi.org/10.1038/nchembio.2007.5

[13] M. Dunkel, U. Schmidt, S. Struck, L. Berger, B. Gruening, J. Hossbasch, I. S. Jaeger, U. Effmert, B. Piechulla, R. Eriksson, J. Knudsen and R. Preissner, "SuperScentA Database of Flavors and Scents," Nucleic Acids Research, Vol. 37, Suppl. 1, 2009, pp. D291-D294. http://dx.doi.org/10.1093/nar/gkn695

[14] H. Wagner and S. Bladt, "Plant Drug Analysis. A Thin Layer Chromatography Atlas," Springer Verlag, Berlín, 1996.

[15] A. Omata, S. Nakamura, K. Yomogida, K. Moriai, Y. Ichikawa and I. Watanabe, "Volatile Components of ToYo-Ran Flowers (Cymbidium-faberi and Cymbidium-virescens)," Agricultural and Biological Chemistry, Vol. 54, No. 4, 1990, pp. 1029-1033. http://dx.doi.org/10.1271/bbb1961.54.1029

[16] J. J. Sadler, J. M. Smith, L. W. Zettler, H. T. Alborn and L. W. Richardson, "Fragance Composition of Dendrophylax lindenii (Orchidaceae) Using a Novel Technique Applied in Situ," Journal of Environmental Sciences, Vol. 1, No. 2, 2011, pp. 137-141.

[17] G. P. P. Kamatou and A. M. Viljoen, "Linalool-A Review of a Biologically Active Compound of Commercial Importance," Natural Product Communications, Vol. 3, No. 7, 2008, pp. 1183-1192.

[18] A. Sousa, I. C. Ferreira, R. Calhelha, P. B. Andrade, P. Valentão, R. Seabra, L. Estevinho, A. Bento and J. A. 
Pereira, "Phenolics and Antimicrobial Activity of Traditional Stoned Table Olives 'Alcaparra'," Bioorganic \& Medicinal Chemistry, Vol. 14, No. 24, 2006, pp. 85338538. http://dx.doi.org/10.1016/j.bmc.2006.08.027

[19] X. Zhu, H. Zhang and R. Lo, "Phenolic Compounds from the Leaf Extract of Artichoke (Cynara scolymus L.) and Their Antimicrobial Activities," Journal of Agricultural and Food Chemistry, Vol. 52, No. 24, 2004, pp. 72727278. http://dx.doi.org/10.1021/jf0490192

[20] I. Oliveira, A. Sousa, I. C. Ferreira, A. Bento, L. Estevinho and J. A. Pereira, "Total Phenol, Antioxidant Potential and Antimicrobial Activity of Walnut (Juglans regia L.) Green Husks," Food and Chemical Toxicology, Vol. 46, No. 7, 2008, pp. 2326-2331.

http://dx.doi.org/10.1016/j.fct.2008.03.017

[21] M. Maridass, M. I. Hussain and G. Rajua, "Phytochemical Survey of Orchids in the Tirunelveli Hills of South India," Ethnobotanical Leaflets, Vol. 2008, No. 12, 2008, pp. 705-712.

[22] C. A. Williams, "The Leaf Flavonoids of the Leaf the Orchidaceae," Phytochemistry, Vol. 18, No. 5, 1970, pp. 803-813.

http://dx.doi.org/10.1016/0031-9422(79)80019-9 